\title{
Pavement induced soil warming accelerates leaf budburst of ash trees
}

\author{
Yuanyuan Chen ${ }^{\mathrm{a}}$, Xiaoke Wang ${ }^{\mathrm{a}, *}$, Bo Jiang ${ }^{\mathrm{b}}$, Ning Yang ${ }^{\mathrm{a}}, \mathrm{Li} \mathrm{Li}^{\mathrm{a}}$ \\ a State Key Laboratory of Urban and Regional Ecology, Research Center for Eco-Environmental Sciences, Chinese Academy of Sciences, Beijing 100085 , China \\ b Changjiang Water Resources Protection Institute, Wuhan 430051, Hubei, China
}

\section{A R T I C L E I N F O}

\section{Article history:}

Received 3 April 2015

Received in revised form 8 November 2015

Accepted 29 January 2016

Available online 2 February 2016

\section{Keywords:}

Ash trees

Impervious pavement

Leaf budburst

Pervious pavement

Soil temperature

Soil moisture content

\begin{abstract}
A B S T R A C T
Urban greening is becoming increasingly popular in cities around the world, which is leading to the planting of more and more trees in paved areas in urban environments. However scientifically it is not well understood how pavement may impact tree greening efforts. In this paper, we investigated plant responses to pavement in the suburb of Changping District, Beijing, China. We planted the popular deciduous ash tree (Fraxinus chinensis) in three different pavements: pervious bricks; impervious bricks; and no pavement (i.e., control) at three densities $(0.5 \mathrm{~m} \times 0.5 \mathrm{~m}, 1.0 \mathrm{~m} \times 1.0 \mathrm{~m}$, and $2.0 \mathrm{~m} \times 2.0 \mathrm{~m}$ apart $)$. We investigated the influence of pavement type on plant phenology by monitoring soil temperature and moisture as well as leaf budburst rate from January to April in 2014. Our results show that pavement can significantly increase soil temperature, and decreased soil moisture except pervious pavement at the $1.0 \mathrm{~m} \times 1.0 \mathrm{~m}$ density. The significant relationship between the leaf budburst rate and accumulated soil temperature implies that pavement induced soil warming can accelerate leaf budburst, suggesting that pavement contributes to tree leaf budburst acceleration by probably both increasing soil and air temperatures in urban environments.
\end{abstract}

(C) 2016 Elsevier GmbH. All rights reserved.

\section{Introduction}

The majority of urban environments are paved in order to provide residents efficient and safe built infrastructure like parking lots, roads and driveways, which are important for urban transportation. A pavement is defined as the land in urban environments covered with artificial materials like concrete, asphalt and bricks (Viswanathan, 2010). Although pavements are convenient for social and economic activities, pavements are known to have adverse impacts on the environment, including increasing stormwater runoff due to the reduction in water infiltration (Lee and Heaney, 2003), enhancing air and ground surface temperature due to greater absorption of short-wave radiation by low reflectivity surfaces (Asaeda et al., 1996) and reducing evaporative cooling rates of soil and plants (Viswanathan, 2010), blocking soil-air gas exchange (Feng et al., 2002), and reducing carbon storage (Zhao et al., 2012). The expansion of pavement reduces the land available for building green infrastructure and growing trees. Trees can provide many services to help mitigate the adverse effects of pavements in urban environments (Ridder et al., 2004). These include reducing stormwater flows by increasing rainfall

\footnotetext{
* Corresponding author. Tel.: +86 1062943822 .

E-mail address: wangxk@rcees.ac.cn (X. Wang).
}

interception (Xiao and McPherson, 2002), reducing the urban heat island effect through evaporative cooling and shade provision (Shashua-Bar et al., 2010; Viswanathan, 2010), improving air quality via absorption of particulate pollutants (Beckett et al., 1998) and reducing noise (Lohr et al., 2004). Thus urban afforestation is becoming a common practice in many cities. In China, urban green space coverage has increased from $16.9 \%$ in 1986 to $23.0 \%$ in 2000, and the area per capita has increased by $3 \mathrm{~m}^{2}$ between 1986 and 2000 (Wang, 2009). Furthermore the area of green space has shown net increases in three major UK cities from 1991 to 2006 (Dallimer et al., 2011). New York City, USA launched the Million Trees NYC initiative to plant 600,000 trees, which include street trees and approximately 809 ha of forest restoration (New York City Department of Parks and Recreation, 2007).

Because most of urban land has been paved for providing transportation and human activity and the amount of available unbuilt land for tree planting is very limited in cities, many trees have to be planted in paved environments. Unfortunately, trees planted in impervious pavement often have poorer growth (Mueller and Day, 2005), and even more 50\% decrement of shoot and root growth than those in the field (Grabosky et al., 2001). Compared to vegetated surfaces, impervious pavements can store more heat and conduct the heat into the soil layer increasing the soil temperature (Tang et al., 2011), which may weaken root growth and even kill tree roots when temperatures are too high (Celestian and Martin, 2004). 
Impervious pavements restrict water penetration into the rhizospheric soil of trees thereby decreasing water availability for tree uptake (Kozlowski, 1999; Balakina et al., 2005; Mueller and Day, 2005). Impervious pavement also can affect soil physiochemical properties, nutrient availability, and microbial characterizations, which can result in the reduction of soil net potential mineralization and nitrification (Zhao et al., 2012).

In recent years, one approach to make the soil beneath pavements more conducive to tree growth is to use pervious surfaces such as porous concrete, porous asphalt and permeable interlocking concrete pavers (Volder et al., 2009; Morgenroth and Visser, 2011; Mullaney and Lucke, 2014; Mullaney et al., 2015). The pores of pervious surfaces can facilitate the movement of water through the surface into the soil profile (Bean et al., 2007; Dietz, 2007). Pervious pavements could increase tree stem height, diameter, and biomass of Oriental Plane tree seedlings (Morgenroth and Visser, 2011). However, the results are not always consistent for all experiments. Root biomass was significantly enhanced beneath pervious pavements relative to impervious pavements in the absence of a compacted subgrade and gravel base, but was unaffected by pavements when there was a compacted subgrade and gravel base (Morgenroth, 2011). The relative growth rates of tree trunk diameters were similar across three different pavement types (no pavement, pervious porous concrete and impervious standard concrete pavements) (Volder et al., 2009). Therefore, we design a factorial split plot experiment to verify the different effects between pervious and impervious pavement on environment and tree growth.

Plant phenology, which is the timing of plant growing events (e.g., leaf budburst, flowering, coloration, and falling), is an important indicator for describing plant responses to environmental changes such as variations in air temperature, photoperiod, precipitation, soil moisture, and evaporation (Zhao and Schwartz, 2003; Neil and Wu, 2006; Cleland et al., 2007). However, there are few investigations on plant phenology in response to pavement in urban environments. Leaf budburst is an important plant phenological phase since it marks the starting period of tree growth in a new year, and is known to be one of the most sensitive indicators to environmental change (Neil and Wu, 2006; Doi and Katano, 2008). Air temperature is recognized as the dominant factor controlling leaf budburst (Menzel and Fabian, 1999; White et al., 2002; Primack et al., 2004; Zhang et al., 2004). In urban areas, it has been reported that pavement enhances the air temperature because it stores more energy than vegetation (Kjelgren and Montague, 1998; Hung et al., 2006). Leaf budburst would be accelerated because the rate of pavement induced urban warming is much greater than the global average climate warming as a result of the impervious concrete surfaces (Luo et al., 2007). This is attributed to the urban heat island effect where impervious surfaces hold heat more than pervious surfaces and thus the air temperature in urban areas is often increased compared to rural areas. A large number of studies reported that the spring greening in urban environments is earlier than in the suburbs due to urban heat island effect (Roetzer et al., 2000; Fitter and Fitter, 2002; White et al., 2002; Zhang et al., 2004). Anecdotal observations have shown that springs are warmer in recent decades (Zhang et al., 2005), leading to notable advancement in leaf budburst. For instance, the leaf budburst dates have advanced during the past five decades in four Japanese localities (Doi and Katano, 2008). In China, the advancements of the starting date of tree greening have been reported in highly urbanized regions, such as in the Yangtze River Delta Region (Han et al., 2008) and in Beijing (Luo et al., 2007).

Overlying pavements could alter the trees growing environment not only by increasing air temperature, but more importantly, by changing the physical and chemical characteristics of the soil (Celestian and Martin, 2004; Morgenroth et al., 2013). However, there has been no investigation on the impacts of pavements on plant phenology (e.g., leaf budburst) in relation to the soil microenvironment, specifically soil temperature and moisture. The direct influence of pavement induced environmental factors other than air temperature on leaf budburst acceleration in urban areas is largely unknown.

This paper aims to investigate seedling responses to different pavement environments with different planting densities. Soil temperature and moisture and leaf budburst rate were monitored to address the following questions: (1) What changes to soil temperature and moisture and leaf budburst can occur under pavements? (2) What factors contribute to phenological changes because of pavement? (3) Are there differences in spring soil temperature and moisture and leaf phenology between pervious and impervious pavement?

\section{Materials and methods}

\subsection{Site description}

A field experiment was conducted at Zhangtou village, Changping District, Beijing, China $\left(40^{\circ} 12^{\prime} \mathrm{N}, 116^{\circ} 08^{\prime} \mathrm{E}\right)$. It is a temperate continental monsoon climate, with four distinct seasons. The average annual rainfall is $542 \mathrm{~mm}$ with the majority of the rainfall occurring from June to September. Annual mean temperature is $12.1^{\circ} \mathrm{C}$ and the maximum and minimum air temperatures are $41.4^{\circ} \mathrm{C}$ and $-19.6^{\circ} \mathrm{C}$, respectively (Local Chronicles Office of Changping District of Beijing, 2012). The soil texture at the test site is defined as sandy loam, and the bulk density is $1.5 \mathrm{~g} \mathrm{~cm}^{-3}$, mean soil organic matter content is $16.4 \mathrm{~g} \mathrm{~kg}^{-1}$, total nitrogen $0.9 \mathrm{~g} \mathrm{~kg}^{-1}$, available phosphorus $38.1 \mathrm{mg} \mathrm{kg}^{-1}$, available potassium $102.1 \mathrm{mg} \mathrm{kg}^{-1}$, and soil $\mathrm{pH}$ value 8.3 (Tong et al., 2011).

\subsection{Experimental design}

A factorial split plot experimental design was used to divide the study area into three equal zones along the width edge for three pavement types: (1) pervious bricks pavement, (2) impervious bricks pavement, and (3) no pavement (i.e., control). In each zone, we used three blocks as replicates, and within each block we had three plots with different densities: (1) 23 trees with a density of $0.5 \mathrm{~m} \times 0.5 \mathrm{~m}$, (2) 23 trees with a density of $1.0 \mathrm{~m} \times 1.0 \mathrm{~m}$, and (3) 18 trees with a density of $2.0 \mathrm{~m} \times 2.0 \mathrm{~m}$. In summary there were nine different treatments (three pavements and three densities) with three replicates (Fig. 1). The plot areas were 9, 25, and $80 \mathrm{~m}^{2}$ for $0.5 \mathrm{~m} \times 0.5 \mathrm{~m}, 1.0 \mathrm{~m} \times 1.0 \mathrm{~m}$, and $2.0 \mathrm{~m} \times 2.0 \mathrm{~m}$ plant density, respectively. Zones were segregated by a shallow drainage ditch. Prior to the experiment, the land was cultivated for wheat and maize production for many years. The land zones for treatments of pervious and impervious pavements were compacted and leveled before the bricks were paved. All bricks were paved tightly on the soil surface side by side. The gaps between bricks were filled with clay soil to prevent water infiltration. Pits of $20 \mathrm{~cm} \times 20 \mathrm{~cm}$ were created before the bricks were paved to plant the trees according to the different densities. All bricks are grey, and the size was $20 \mathrm{~cm} \times 10 \mathrm{~cm} \times 6 \mathrm{~cm}$ (length $\times$ width $\times$ height) The bricks were produced from a mixture of clay, sand, and coal ash by Beijing Yataiyuhong Technology Development Co., Ltd. Due to a different mixing ratio, the pervious brick has a coarse surface and is porous while the impervious brick surface is smooth and not porous. The pervious capability of pervious bricks is more than $0.4 \mathrm{~mm} \mathrm{~s}^{-1}$ (manufacturer data).

One year old ash tree (Fraxinus chinensis) seedlings were randomly planted on April 16, 2012. Ash trees were chosen as they are a common urban tree species in Beijing. Before the trees were planted 


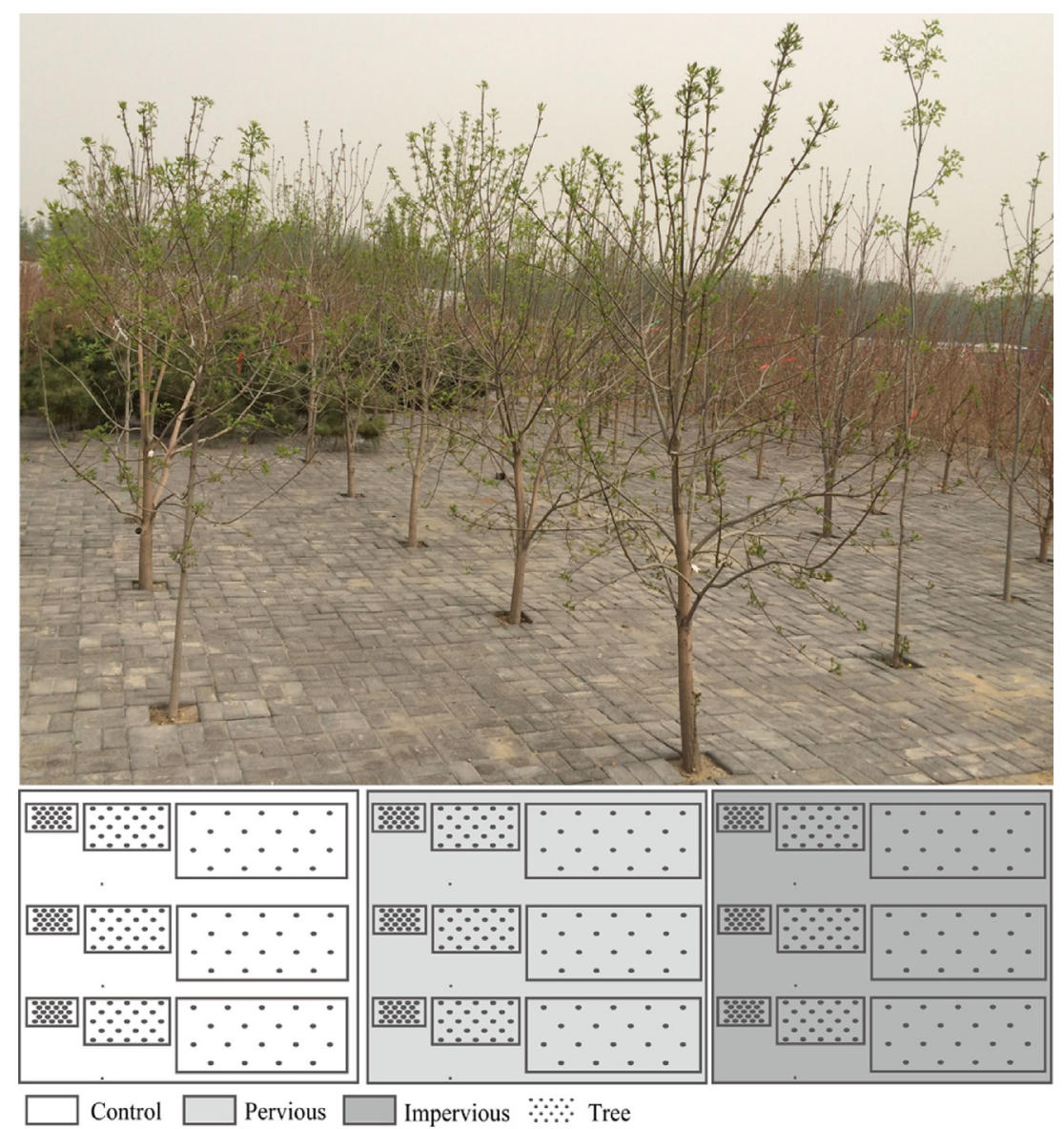

Fig. 1. A photograph of a sample plot (upper) and a diagram of the experimental design (lower).

the height and diameter of all trees were measured using a ruler and vernier caliper, respectively. The average height of the seedlings was $118.5 \pm 2.4 \mathrm{~cm}$, and the average diameter was $14.8 \pm 1.0 \mathrm{~mm}$.

\subsection{Measurements}

To evaluate the impact of pavement type on tree phenology, soil temperature, soil moisture and leaf budburst rates were measured. After one year from when the trees were planted (April 2013), soil temperature and soil moisture sensors were installed at a soil depth of $20 \mathrm{~cm}$ from the soil surface in each plot. Soil temperature was measured using T-thermocouple interfaced with a Campbell CR1000 data logger (Campbell Scientific, Inc., Logan, UT, U.S.), and soil moisture was measured using $\mathrm{ECH}_{2} \mathrm{O}$ EC-5 probes, which were inserted with the flat surface parallel to the soil surface and interfaced with an EM50 data logger (Decagon Devices, Inc., Pullman, WA, U.S.). Soil temperature and soil moisture were recorded every 10 min from April 2013 to April 2014. Three soil samples were collected from each plot on March 26, 2014, then air-dried. Soil total nitrogen and organic matter were measured by elemental analyzer (Vario EL III, Elementar, Germany). Leaf budburst rate is recorded and defined as the percentage of trees in which more than $50 \%$ of shoots are beginning to sprout for each plot on April 7, 2014.

\subsection{Statistical analysis}

Paired-Samples $T$ test was used to identify the differences of soil temperature and soil moisture between pavement types for each tree density and between tree densities for each pavement types. Two-way analysis of variance (ANOVA) was used to analyze the difference in soil total nitrogen, soil organic matter content, and leaf budburst rates. Post-hoc least significant difference tests were performed only when significant differences were detected by ANOVA. The differences or interactions among treatments were regarded as statistically significant when the $P$ value was less than the significance level of 0.05 . We analyzed the relationship between leaf budburst rate and accumulated soil temperature when mean daily soil temperature was higher than $5^{\circ} \mathrm{C}$ using regression statistics. All statistical analyses were carried out using the SPSS 16.0 software (SPSS Inc., Chicago, IL, USA).

\section{Results}

\subsection{Soil total nitrogen and soil organic matter content}

Soil total nitrogen and organic matter content results ranged from $0.87-1.15 \mathrm{~g} \mathrm{~kg}^{-1}$ and $16.52-22.57 \mathrm{~g} \mathrm{~kg}^{-1}$, respectively across the pavement types and planting densities (Table 1 ). There were no statistically significant differences in the soil total nitrogen and organic matter content among treatments through two-way ANVOA (Table 1).

\subsection{Soil temperature and soil moisture}

Pavements had significantly higher soil temperatures than the control for all tree densities from January to April 2014 (Fig. 2). The Paired-Samples $T$ test (Table 2) showed that the pervious and impervious pavements had significantly higher soil temperatures than the control for all tree densities across the entire study period from January to April 2014. The difference in soil temperature between pervious and impervious pavements varied across the three different densities. The difference in soil temperature 
Table 1

The effects of pavements and densities on soil total nitrogen and soil organic matter content were analyzed by two-way ANOVA.

\begin{tabular}{|c|c|c|c|}
\hline Density & Pavement & Soil total nitrogen $\left(\mathrm{g} \mathrm{kg}^{-1}\right)$ & Soil organic matter content $\left(\mathrm{g} \mathrm{kg}^{-1}\right)$ \\
\hline $0.5 \mathrm{~m} \times 0.5 \mathrm{~m}$ & $\begin{array}{l}\text { Control } \\
\text { Pervious Pavement } \\
\text { Impervious Pavement }\end{array}$ & $\begin{array}{l}1.00 \pm 0.11 \\
1.08 \pm 0.28 \\
1.03 \pm 0.24\end{array}$ & $\begin{array}{l}20.37 \pm 1.73 \\
19.85 \pm 5.00 \\
20.12 \pm 2.42\end{array}$ \\
\hline $1.0 \mathrm{~m} \times 1.0 \mathrm{~m}$ & $\begin{array}{l}\text { Control } \\
\text { Pervious Pavement } \\
\text { Impervious Pavement }\end{array}$ & $\begin{array}{l}1.02 \pm 0.07 \\
0.97 \pm 0.09 \\
1.15 \pm 0.01\end{array}$ & $\begin{array}{l}20.45 \pm 1.19 \\
17.86 \pm 1.12 \\
20.91 \pm 0.19\end{array}$ \\
\hline $2.0 \mathrm{~m} \times 2.0 \mathrm{~m}$ & $\begin{array}{l}\text { Control } \\
\text { Pervious Pavement } \\
\text { Impervious Pavement }\end{array}$ & $\begin{array}{l}1.13 \pm 0.14 \\
0.97 \pm 0.14 \\
0.87 \pm 0.16\end{array}$ & $\begin{array}{l}22.57 \pm 3.17 \\
18.45 \pm 3.10 \\
16.52 \pm 1.74\end{array}$ \\
\hline $\begin{array}{l}\text { Two-way ANOVA } \\
\text { Pavement } \\
\text { Density } \\
\text { Pavement } \times \text { density }\end{array}$ & & $\begin{array}{l}\text { ns } \\
\text { ns } \\
\text { ns }\end{array}$ & $\begin{array}{l}\text { ns } \\
\text { ns } \\
\text { ns }\end{array}$ \\
\hline
\end{tabular}

Note: ns, not significant $(P>0.05)$.

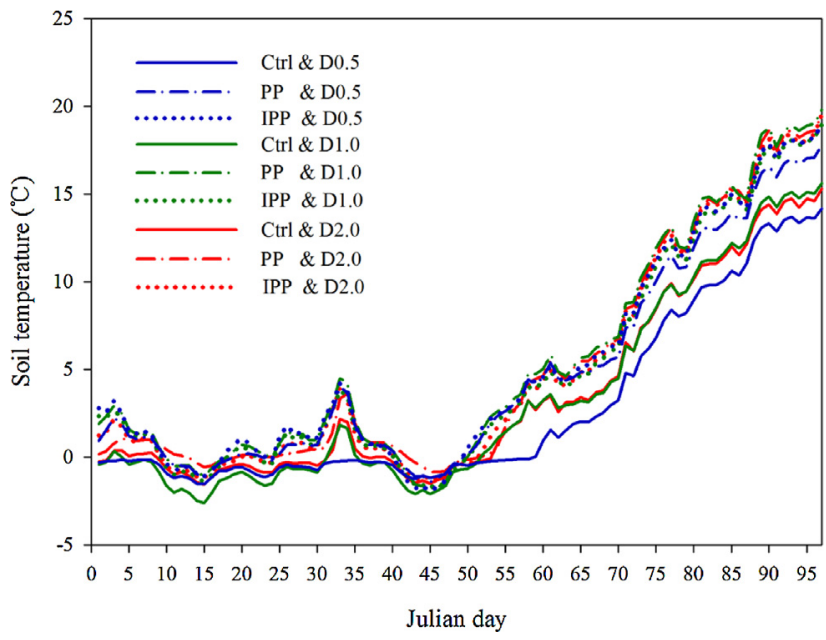

Fig. 2. Effects of different pavements (Control, Ctrl; Pervious pavement, PP; Impervious pavement, IPP) and densities $(0.5 \mathrm{~m} \times 0.5 \mathrm{~m}$ density, D0.5; $1.0 \mathrm{~m} \times 1.0 \mathrm{~m}$ density, $\mathrm{D} 1.0 ; 2.0 \mathrm{~m} \times 2.0 \mathrm{~m}$ density, D2.0) on daily mean soil temperatures.

between pavement types was smaller at the $2.0 \mathrm{~m} \times 2.0 \mathrm{~m}$ density than at the $0.5 \mathrm{~m} \times 0.5 \mathrm{~m}$ and $1.0 \mathrm{~m} \times 1.0 \mathrm{~m}$ densities (Table 2 ). Although there were statistically significant differences in the soil temperature between density treatments, the differences among density treatments varied according to pavement type. The difference in soil temperature between densities was smaller at impervious pavement than at the control and pervious pavement (Table 2).

The Paired-Samples $T$ test (Table 2) showed that the differences in soil moisture between different pavements or densities were statistically significant, except between the two high densities $(0.5 \mathrm{~m} \times 0.5 \mathrm{~m}$ and $1.0 \mathrm{~m} \times 1.0 \mathrm{~m})$ in pervious pavement (Table 2$)$.
The soil moisture was higher in the control than in the impervious pavement for all three density treatments, and higher in pervious pavement than in impervious pavement for two low densities $(1.0 \mathrm{~m} \times 1.0 \mathrm{~m}$ and $2.0 \mathrm{~m} \times 2.0 \mathrm{~m})$. However, the different trends of soil moisture between treatments or densities did not change during the spring period of the experiment (See Fig. 3).

\subsection{Leaf budburst rate of ash and its relationship to accumulated soil temperature}

Ash leaf budburst rate of the pavements were significantly greater than the control for the three density treatments $(P<0.01)$ (Fig. 4). It is worth noting that there were no statistically significant differences between leaf budburst rates under pervious and impervious pavements (Fig. 4). However we found there was a statistically significant interaction effect between pavements and density treatments on leaf budburst. Lastly we found that leaf budburst was linearly and positively correlated with accumulated soil temperature from January to April 2014 when the daily mean soil temperature was greater than $5^{\circ} \mathrm{C}$ (Fig. 5).

\section{Discussion}

Soil temperatures were significantly higher in the pavement treatments compared to the control treatment. In our experiment, the bricks used in the pavements were grey in color and as a result have a low radiation reflectivity and low thermal capacity, which explains the higher surface temperatures. Conduction of thermal energy downward into subjacent soil elevates soil temperatures (Asaeda et al., 1996). In addition, pavement also prevents soil heat dissipation at night, which leads to increases in soil temperature. Our results are consistent with previous studies (Kjelgren and Montague, 1998; Celestian and Martin, 2004; Montague and Kjelgren, 2004), which show that soil temperature of pavements

Table 2

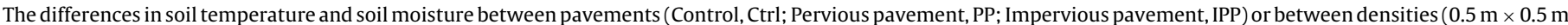
density, D0.5; $1.0 \mathrm{~m} \times 1.0 \mathrm{~m}$ density, D1.0; $2.0 \mathrm{~m} \times 2.0 \mathrm{~m}$ density, D2.0) were analyzed using Paired-Samples $T$ test.

\begin{tabular}{|c|c|c|c|c|c|c|c|c|}
\hline \multirow[t]{2}{*}{ Parameters } & \multirow[t]{2}{*}{ Density } & \multicolumn{3}{|c|}{ Paired differences of the mean value } & \multirow[t]{2}{*}{ Pavement } & \multicolumn{3}{|c|}{ Paired differences of the mean value } \\
\hline & & PP-Ctrl & IPP-Ctrl & IPP-PP & & D1.0-D0.5 & D2.0-D0.5 & D2.0-D1.0 \\
\hline \multirow[t]{3}{*}{ Soil temperature } & D0.5 & $2.00 \pm 1.28^{* *}$ & $2.44 \pm 1.64^{* *}$ & $0.43 \pm 0.62^{* *}$ & Ctrl & $0.59 \pm 1.07^{* *}$ & $0.78 \pm 0.91^{* *}$ & $0.19 \pm 0.51^{* *}$ \\
\hline & D1.0 & $2.09 \pm 1.02^{* *}$ & $1.60 \pm 0.84^{* *}$ & $-0.49 \pm 0.44^{* *}$ & PP & $0.68 \pm 0.75^{* *}$ & $0.38 \pm 0.93^{* *}$ & $-0.29 \pm 0.74^{* *}$ \\
\hline & D2.0 & $1.61 \pm 1.31^{* *}$ & $1.45 \pm 1.21^{* *}$ & $-0.16 \pm 0.63^{* *}$ & IPP & $-0.24 \pm 0.29^{* *}$ & $-0.20 \pm 0.61^{* *}$ & $0.04 \pm 0.65^{* *}$ \\
\hline \multirow[t]{3}{*}{ Soil moisture } & D0.5 & $-5.77 \pm 1.08^{* *}$ & $-3.91 \pm 1.38^{* *}$ & $1.86 \pm 0.78^{* *}$ & Ctrl & $-6.21 \pm 0.75^{* *}$ & $-1.41 \pm 0.84^{* *}$ & $4.81 \pm 0.79^{* *}$ \\
\hline & D1.0 & $0.47 \pm 0.91^{* *}$ & $-2.06 \pm 0.89^{* *}$ & $-2.53 \pm 1.18^{* *}$ & $\mathrm{PP}$ & $0.03 \pm 0.63 \mathrm{~ns}$ & $3.27 \pm 1.06^{* *}$ & $3.24 \pm 1.00^{* *}$ \\
\hline & D2.0 & $-1.10 \pm 0.84^{* *}$ & $-5.07 \pm 1.05^{* *}$ & $-3.97 \pm 1.15^{* *}$ & IPP & $-4.36 \pm 0.71^{* *}$ & $-2.56 \pm 0.57^{* *}$ & $1.80 \pm 0.59^{* *}$ \\
\hline
\end{tabular}

Note: ${ }^{* *}$ significant at 0.01 level; ${ }^{*}$ significant at 0.05 level; ns, not significant. 


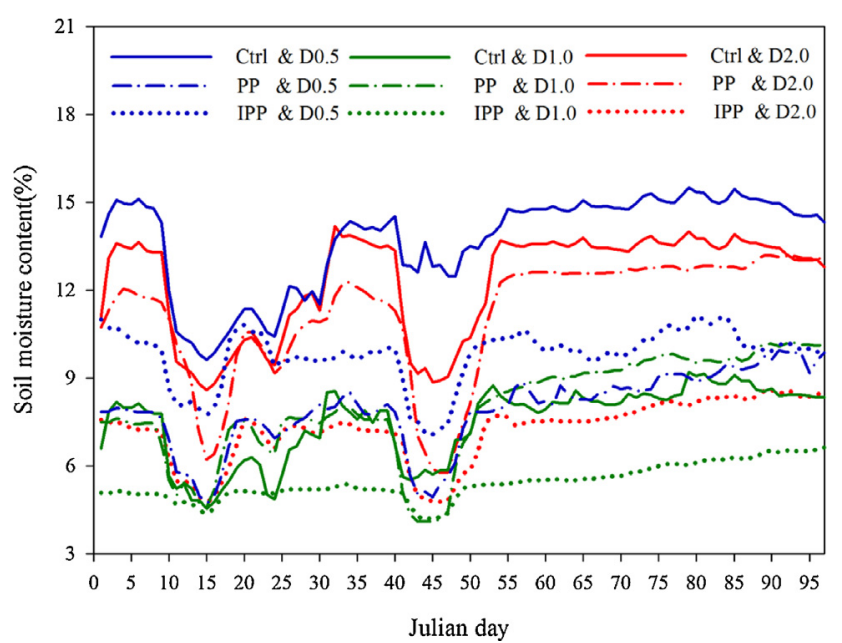

Fig. 3. Effects of different pavements (Control, Ctrl; Pervious pavement, PP; Impervious pavement, IPP) and densities $(0.5 \mathrm{~m} \times 0.5 \mathrm{~m}$ density, D0.5; $1.0 \mathrm{~m} \times 1.0 \mathrm{~m}$ density, D1.0; $2.0 \mathrm{~m} \times 2.0 \mathrm{~m}$ density, D2.0) on daily mean soil moisture.

(e.g., asphalt surfaces) were higher than that of vegetated or mulch landscape surfaces. The low reflectivity and relatively large heat storage capacity of pavements (e.g., asphalt) allows it to absorb and store substantial amounts of heat (Asaeda et al., 1996).

There were statistically significant differences in soil moisture between pavement treatments and density treatments for the majority of plots $(P<0.05, T$-test $)$ and the differences varied with density or pavement type. Soil moisture in the control with no pavement surface was higher than that beneath the plots with impervious pavement surface because the impervious pavements intercept rainwater before it can infiltrate the soil. Previous studies have mainly examined whether pervious pavement increases soil moisture compared to impervious pavement surfaces (Volder et al., 2009; Mullaney et al., 2015). Results have shown that pervious pavements cannot effectively improve the soil moisture content compared to impervious pavement surfaces (Morgenroth and Buchan, 2009; Volder et al., 2009). However, in our study we

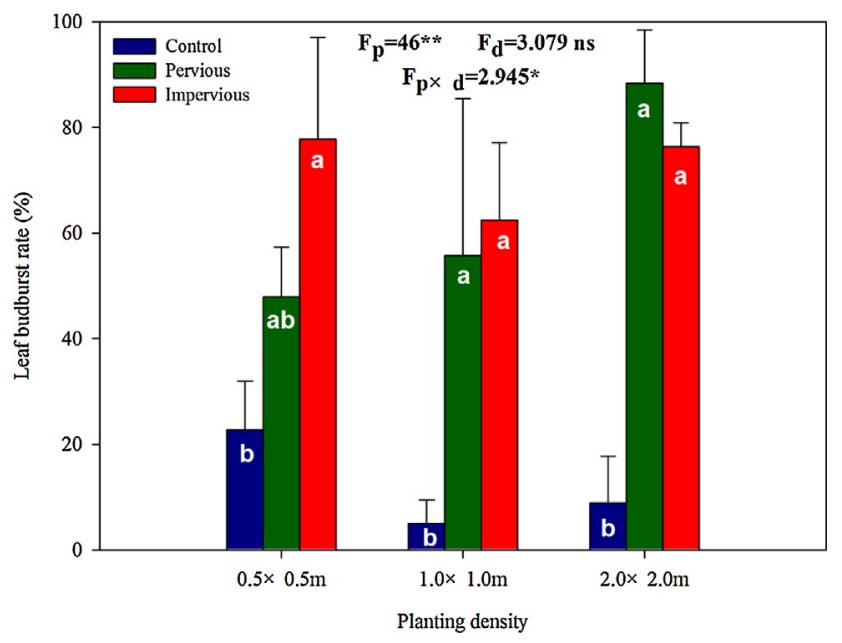

Fig. 4. Leaf budburst rate of ash trees grown on the control (blue bars), pervious (green bars) or impervious pavements (red bars) for three different density treatments. The effects of pavements (p) and densities (d) on leaf budburst rates were analyzed by two-way ANOVA (** significant at 0.01 level; * significant at 0.05 level; ns, not significant). The differences among pavements for each density treatment were analyzed by one-way ANOVA. Different letters for each density treatment denote significant differences among pavements at the significant level of 0.05 . (For interpretation of the references to color in this figure legend, the reader is referred to the web version of this article.)

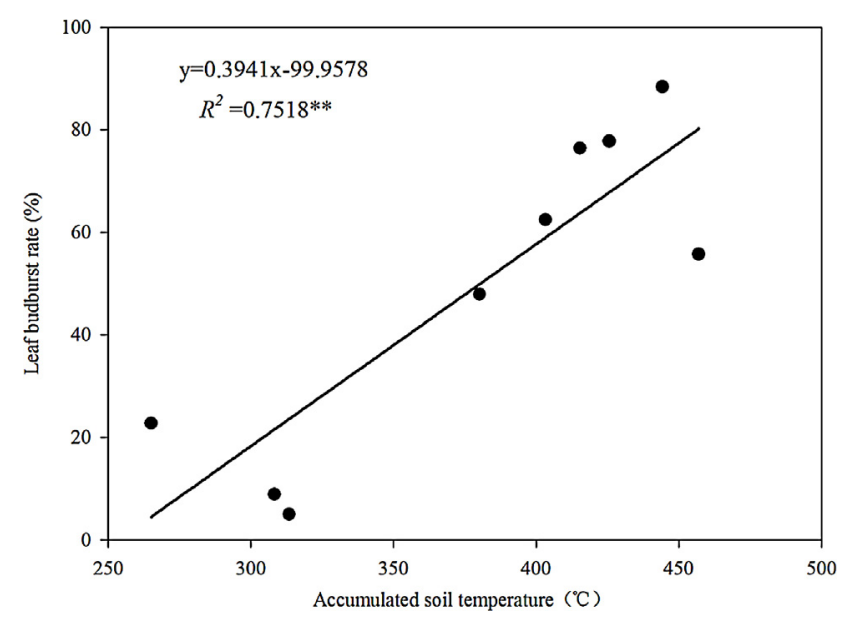

Fig. 5. Correlation between leaf budburst rate and accumulated soil temperature The solid line represents the best-fit linear regressions for treatments $\left({ }^{* *}\right.$ significant at 0.01 level).

showed that the soil moisture is significantly higher $(P<0.05, T$ test) in pervious pavement compared to impervious pavement for two low density treatments $(1.0 \mathrm{~m} \times 1.0 \mathrm{~m}$ and $2.0 \mathrm{~m} \times 2.0 \mathrm{~m})$, but not for the high density treatment $(0.5 \mathrm{~m} \times 0.5 \mathrm{~m})$. More pits for tree planting at high density could penetrate rainwater into soil, so even under impervious pavement soil moisture was not reduced. Other factors would influence the effects of pavement types on soil moisture. For example, pervious pavement had greater soil moisture than impervious pavement for the collar closest to the stem, while no effects of pavement on soil moisture for the outer collar (Viswanathan, 2010). Soil moisture in deeper soil layers below the pervious pavement will have greater soil moisture than that of impervious pavement in all seasons except in the summer (Volder et al., 2009). Soil moisture under pervious pavement was higher compared to under impervious pavement in the sandy loam, but lower in the clay soil, and soil moisture under pervious pavement was related to the depth of the underlying base layer (Mullaney et al., 2015). These inconsistent results may be attributed to the complicated influences of treatments on soil moisture because soil moisture depends on soil texture, pavement materials, soil temperature, rainfall, plant density, seasons.

Air temperature is a main driver of many plant developmental processes (Morin et al., 2010), and higher air temperatures can accelerate plant development thereby leading to earlier switching to the next ontogenetic stage (Saxe et al., 2001). Lu et al. (2006) proposed air temperature was the dominant driving force for changing the phenological phase in a monsoon climate. Air temperature, in our study, being nearly the same between treatments within the distance of less than $100 \mathrm{~m}$ under free air movement, may not change the timing of leaf budburst. In this small scale study, pavement increased soil temperature (Table 2), and would influence the timing of leaf budburst. The relationship between leaf budburst rate and accumulated soil temperature suggest the increment in soil temperature advanced the tree leaf budburst. It can be concluded that soil temperature has the same role as air temperature, and can advance tree phenological phase. Therefore the conclusion is consistent with other studies showing that increased soil temperature has the potential to advance tree phenological phases (Poerwanto and Inoue, 1990; Greer et al., 2005). At the same air temperature of $25^{\circ} \mathrm{C}$ trees required longer days to sprout at the soil temperature of $15^{\circ} \mathrm{C}$ than $25^{\circ} \mathrm{C}$ and $30^{\circ} \mathrm{C}$ (Poerwanto and Inoue, 1990). Both the proportion and timing of budburst of potted mature apple were significantly enhanced as root-zone soil temperature increased in a constant day/night air temperature regime $\left(25 / 18^{\circ} \mathrm{C}\right.$ ) (Greer et al., 2005). The mobilization of stored carbohydrate reserves to support 
developing buds and leaf growth often begins before budburst and always precedes the onset of autotrophic growth (Loescher et al., 1990). Trees store carbohydrates predominantly in fine and coarse roots (Greer and Wünsche, 2003), increasing soil temperatures could stimulate root metabolic activities to produce soluble carbohydrate (Browse, 2002) and synthesize cytokinin (O'Hare, 2004), then accelerate leaf budburst. Therefore, in the urban environment, the earlier observed phenological phase might not only be related to air temperature but also soil temperature (due to land pavement). However, it is necessary to conduct more studies to improve our understanding on the confounding effects of air temperature and soil temperature induced by pavements on phenology to verify this conclusion.

Tree density was another co-factor that we investigated in this study and we found that density influenced soil temperature and moisture and leaf budburst relative to pavement type. For example, for the control plots, we observed delayed leaf budburst under low density treatment, but observed advanced leaf budburst for pervious pavement under low density treatment.

Pavement can change multiple environmental factors that can influence tree development and growth. Therefore more factors are needed to be monitored in further study.

\section{Conclusions}

Planting trees in pavement is very popular in urban environments, however there has been minimal investigation of the impact of pavement on microenvironments, and its influence on tree growth and phenology. This study supports the hypothesis that pavement can increase soil temperature, and thus advance the leaf budburst of urban trees. The advance of leaf budburst could extend the growing period and enhance tree growth, if leaf senescence is not altered. Our study showed that the advance of leaf budburst had a significant relationship with accumulated soil temperature, indicating that tree phenology is not only related to air temperature, but also can be influenced by soil temperature. These findings highlight the importance of monitoring the effect of air and soil temperature variation on several tree species for longer time-periods to better assess the effect of pavement on plant phenology and growth, including the different effects of pervious and impervious pavement on plant phenology and growth.

\section{Acknowledgments}

We would like to thank Dr. Christina P. Wong (School of Sustainability, Arizona State University) for her professional assistance on editing the English and her suggestions on the manuscript. This research was supported by China Special Fund for Forestry Research in Public Interest (201304301), National Nature Science foundation of China (41571053, 71533005), Research Center for Eco-Environmental Sciences, Chinese Academy of Sciences ('135' project). We also would like to thank the editors and reviewers for their valuable comments, which improved the manuscript.

\section{References}

Asaeda, T., Ca, V.T., Wake, A., 1996. Heat storage of pavement and its effect on the lower atmosphere. Atmos. Environ. 30 (3), 413-427.

Balakina, J.N., Makarova, O.V., Bondarenko, V., Koudstaal, L.J., Ros, E.J., Koolen, A.J., van Loon, W.K.P., 2005. Simulation of oxygen regime of tree substrates. Urban For. Urban Greening 4, 23-35.

Bean, E.Z., Hunt, W.F., Bidelspach, D.A., 2007. Field survey of permeable pavement surface infiltration rates. J. Irrig. Drain. Eng. 133, 249-255.

Beckett, K.P., Freer-Smith, P.H., Taylor, G., 1998. Urban woodlands: their role in reducing the effects of particulate pollution. Environ. Pollut. 99, 347-360.

Browse, J., 2002. Respiration and lipid metabolism. In: Taiz, L., Zeiger, E. (Eds.), Plant Physiology. , third ed. Sinauer Associates, Sunderland, MA, pp. 223-258.
Celestian, S.B., Martin, C.A., 2004. Rhizosphere, surface, and air temperature patterns at parking lots in Phoenix, Arizona, U.S. J. Arboricult. 30, 245-252.

Cleland, E.E., Chuine, I., Menzel, A., Mooney, H.A., Schwartz, M.D., 2007. Shifting plant phenology in response to global change. Trends Ecol. Evol. 22 (7), 357-365.

Dallimer, M., Tang, Z.Y., Bibby, P.R., Brindley, P., Gaston, K.J., Davies, Z.G., 2011. Temporal changes in greenspace in a highly urbanized region. Biol. Lett. 7 , 763-766.

Dietz, M.E., 2007. Low impact development practices: a review of current research and recommendations for future directions. Water Air Soil Pollut. 186, 351-363.

Doi, H., Katano, I., 2008. Phenological timings of leaf budburst with climate change in Japan. Agric. For. Meteorol. 148, 512-516.

Feng, G., Wu, L., Letey, J., 2002. Evaluating aeration criteria by simultaneous measurement of oxygen diffusion rate and soil-water regime. Soil Sci. 167 (8), 495-503.

Fitter, A.H., Fitter, R.S.R., 2002. Rapid changes in flowering time in British plants. Science 296, 1689-1691.

Grabosky, J., Bassuk, N., Irwin, L., Van Es, H., 2001. Shoot and root growth of three tree species in sidewalks. J. Environ. Hortic. 19 (4), 206-211.

Greer, D.H., Wünsche, J.N., 2003. Late-season temperature effects on the carbon economy and tree performance of 'Royal gala' apple (Malus domestica) trees. New Z. J. Crop Hortic. Sci. 31, 235-245.

Greer, D.H., Wünsche, J.N., Norling, C.L., Wiggins, H.N., 2005. Root-zone temperatures affect phenology of bud break, flower cluster development, shoot extension growth and gas exchange of 'Braeburn' (Malus domestica) apple trees. Tree Physiol. 26, 105-111.

Han, G.F., Xu, J.H., Yuan, X.Z., 2008. Impact of urbanization on vegetation phenology in major cities in Yangtze River Delta region. Chin. J. Appl. Ecol. 19 (8), 1803-1809 (In Chinese, with English summary).

Hung, T., Uchihama, D., Ochi, S., Yasuoka, Y., 2006. Assessment with satellite data of the urban heat island effects in Asian mega cities. Int. J. Appl. Earth Observ. Geoinfor. 8, 34-48.

Kjelgren, R., Montague, T., 1998. Urban tree transpiration over turf and asphalt surfaces. Atmos. Environ. 32, 35-41.

Kozlowski, T.T., 1999. Soil compaction and growth of woody plants. Scand. J. For. Res. 14, 596-619.

Lee, J.G., Heaney, J.P., 2003. Estimation of urban imperviousness and its impacts on storm water systems. J. Water Resour. Plann. Manage. 129, 419-426.

Local Chronicles Office of Changping District of Beijing, 2012. Beijing Changping Yearbook, 2012. The History of the Communist Party of China Publishing House, Beijing (In Chinese).

Loescher, W.H., McCamant, T., Keller, J.D., 1990. Carbohydrate reserves, translocation and storage in woody plant roots. Hortic. Sci. 25, 274-281.

Lohr, V.L., Pearson-Mims, C.H., Tarnai, J., Dillman, A., 2004. How urban residents rate and rank the benefits and problems associated with trees in cities. J. Arboric. 30, 28-35.

Lu, P.L., Yu, Q., Liu, J.D., Lee, X.H., 2006. Advance of tree-flowering dates in response to urban climate change. Agric. For. Meteorol. 138, 120-131.

Luo, Z.K., Sun, O.J., Ge, Q., Xu, W.T., Zheng, J.J., 2007. Phenological responses of plants to climate change in an urban environment. Ecol. Res. 22 (3), 507-514.

Menzel, A., Fabian, P. 1999. Growing season extended in Europe Nature 397, 659.

Montague, T., Kjelgren, R.K., 2004. Energy balance of six common landscape surfaces and the influence of surface properties on gas exchange of four containerized tree species. Sci. Hortic. 100, 229-249.

Morgenroth, J., 2011. Root growth response of Platanus orientalis to porous pavements. Arboric. Urban For. 37 (2), 45-50.

Morgenroth, J., Buchan, G., 2009. Soil moisture and aeration beneath pervious and impervious pavements. Arboric. Urban For. 35 (3), 135-141.

Morgenroth, J., Buchan, G., Scharenbroch, B.C., 2013. Belowground effects of porous pavements-Soil moisture and chemical properties. Ecol. Eng. 51, 221-228.

Morgenroth, J., Visser, R., 2011. Above-ground growth response of Platanus orientalis to porous pavements. Arboric. Urban For. 37, 1-5.

Morin, X., Roy, J., Sonié, L., Chuine, I., 2010. Changes in leaf phenology of three European oak species in response to experimental climate change. New Phytol. 186, 900-910.

Mueller, E.C., Day, T.A., 2005. The effect of urban ground cover on microclimate, growth and leaf gas exchange of oleander in Phoenix, Arizona. Int. J. Biometeorol. 49, 244-255.

Mullaney, J., Lucke, T., 2014. Practical review of pervious pavement designs. Clean-Soil Air Water 42, 111-124.

Mullaney, J., Lucke, T., Trueman, S.J., 2015. The effect of permeable pavements with an underlying base layer on the growth and nutrient status of urban trees. Urban For. Urban Greening 14, 19-29.

Neil, K., Wu, J.G., 2006. Effects of urbanization on plant phenology: a review. Urban Ecosyst. 9, 243-257.

New York City Department of Parks and Recreation, 2007. Mayor Bloomberg and Bette Midler Plant the First of One Million Trees and Launch Million Trees NYC. NYC Parks, Available at: 〈http://www.nyc.gov/portal/site/nycgov/menuitem. c0935b9a57bb4ef3daf2f1c701c789a0/index.jsp?pageID=mayor_press_release\& catID=1194\&doc_name=http\%3A\%2F\%2Fwww.nyc.gov\%2Fhtml\%2Fom\%2Fhtml\% 2F2007b\%2Fpr359-07.html\&cc=unused1978\&rc=1194\&ndi=1 $\rangle$ (accessed 5 June 2013).

O'Hare, T.J., 2004. Impact of root and shoot temperature on bud dormancy and floral induction in lychee (Litchi chinensis Sonn.). Sci. Hortic. 99, 21-28. 
Poerwanto, R., Inoue, H., 1990. Effects of air and soil temperatures on flower development and morphology of satsuma mandarin. J. Hortic. Sci. 65 (6), 739-745.

Primack, D., Imbres, C., Primack, R.B., Milier-Rushing, A.J., Tredici, P.D., 2004. Herbarium specimens demonstrate earlier flowering times in response to warming in Boston. Am. J. Bot. 91, 1260-1264.

Ridder, K.D., Adamec, V., Bañuelos, A., Bruse, M., Bürger, M., Damsgaard, O., Dufek J., Hirsch, J., Lefebre, F., Pérez-Lacorzana, J.M., Thierry, A., Weber, C., 2004. An integrated methodology to assess the benefits of urban green space. Sci. Total Environ. 334-335, 489-497.

Roetzer, T., Wittenzeller, M., Haeckel, H., Nekovar, J., 2000. Phenology in central Europe-differences and trends of spring phenophases in urban and rural areas. Int. J. Biometeorol. 44 (2), 60-66.

Saxe, H., Cannell, M.G.R., Johnsen, B., Ryan, M.G., Vourlitis, G., 2001. Tree and forest functioning in response to global warming. New Phytol. 149, 369-399.

Shashua-Bar, L., Potchter, O., Bitan, A., Boltansky, D., Yaakov, Y., 2010. Microclimate modelling of street tree species effects within the varied urban morphology in the Mediterranean city of Tel Aviv, Israel. Int. J. Climatol. 30, 44-57.

Tang, C.S., Shi, B., Gao, L., Daniels, J.L., Jiang, H.T., Liu, C., 2011. Urbanization effect on soil temperature in Nanjing, China. Energy Build. 43 (11), 3090-3098.

Tong, L., Wang, X.K., Zheng, F.X., Geng, C.M., Wang, W., Yin, B.H., Sui, L.H., Wang, Q. Feng, Z.W., 2011. Effect of Ethylenediurea (EDU) on growth of ozone-stressed rice (Oryza sativa L.) and wheat (Triticum aestivum L.). Asian J. Ecotoxicol. 3 272-280 (In Chinese, with English summary).
Viswanathan, B., 2010. Effect of Pervious and Impervious Pavement on the Rhizospher of American Sweetgum (Liquidambar styraciflua). Texas A\&M University, Texas, Master of Science Thesis.

Volder, A., Watson, T., Viswanathan, B., 2009. Potential use of pervious concrete for maintaining existing mature trees during and after urban development. Urban For. Urban Greening 8, 249-256.

Wang, X.J., 2009. Analysis of problems in urban green space system planning in China. J. For. Res. 20 (1), 79-82.

White, M.A., Nemani, R.R., Thornton, P.E., Running, S.W., 2002. Satellite evidence of phenological differences between urbanized and rural areas of the eastern United States deciduous broadleaf forest. Ecosystems 5 (3), 260-273.

Xiao, Q., McPherson, E.G., 2002. Rainfall interception by Santa Monica's municipal urban forest. Urban Ecosyst. 6, 291-302.

Zhang, X.X., Ge, Q.S., Zheng, J.Y., 2005. Impacts and lags of global warming on vegetation in Beijing for the last 50 years based on remotely sensed data and phenological information. Chin. J. Ecol. 24, 123-130 (In Chinese, with English summary).

Zhang, X.Y., Friedl, M.A., Schaaf, C.B., Strahler, A.H., 2004. Climate controls on vegetation phenological patterns in northern mid- and high latitudes inferred from MODIS data. Global Change Biol. 10, 1133-1145.

Zhao, D., Li, F., Wang, R.S., Yang, Q.R., Ni, H.S., 2012. Effect of soil sealing on the microbial biomass, $\mathrm{N}$ transformation and related enzyme activities at various depths of soils in urban area of Beijing, China. J. Soils Sediments 12, 519-530.

Zhao, T.T., Schwartz, M.D., 2003. Examining the onset of spring in Wisconsin. Clim. Res. 24, 59-70. 